\title{
Employment Discrimination Based on Age: Part II: Applying the ADEA in Employment Scenarios: Discrimination, Idle Chatter, or Something Else?
}

\author{
Richard J. Hunter, Jr. (Corresponding Author) \\ Stillman School of Business, Seton Hall University \\ 400 South Orange Avenue \\ South Orange, New Jersey, USA \\ E-mail: hunterri@shu.edu \\ John H. Shannon \\ Stillman School of Business, Seton Hall University \\ 400 South Orange Avenue \\ South Orange, New Jersey, USA \\ E-mail: John.Shannon@shu.edu
}

\author{
Henry J. Amoroso \\ Stillman School of Business, Seton Hall University \\ 400 South Orange Avenue \\ South Orange, New Jersey, USA \\ E-mail: Henry.Amoroso@shu.edu
}

Received: Dec. 26, 2018 Accepted: Jan. 11, 2019 Online published: Jan. 22, 2019

doi:10.5296/jpag.v9i1.14253ＵRL: https://doi.org/10.5296/jpag.v9i1.14253

\begin{abstract}
This article is Part II of a study on the effects of age discrimination in the workplace. In Part I, we considered the origins of the debate on age discrimination and looked at the demographic
\end{abstract}


information that led to the passage of the Age Discrimination in Employment Act (ADEA) in 1967. In Part II, we raise an important question: Is age discrimination still a real problem? The article analyzes the Act through an application to two employment scenarios by looking at the scope of protection, amendments to the original law, the costs of age discrimination to employers, important exceptions to the ADEA, defenses to ADEA charges, procedures for filing an ADEA claim, and waiver provisions. In addition, the article looks carefully at procedural requirements for filing an ADEA claim, remedies available to an aggrieved party, and to questions relating to retaliation by an employer. Finally, the authors consider the question of employer liability for actions undertaken by employers and other parties which are found to be in violation of the law. In doing so, the authors provide answers to the questions raised in the scenarios described at the outset of the article.

Keywords: age discrimination, Bona Fide Occupational Qualifications, statutory defenses, waivers, retaliation

\section{Introduction: Is This Discrimination?}

Consider these scenarios. Jack Ryker is a faculty member of St. Stephen's University, a private Catholic college, located in Newark, New Jersey. Jack has just reached his seventieth birthday and has been at St. Stephen's for more than thirty five years. At a recent faculty discussion, called together by the dean, another faculty member was commenting about the "unevenness of service activities in the school" and noted that "several of the senior faculty had practically retired in place" and might even consider "moving on." Ryker is deeply troubled by these comments and contacts the dean, voicing his concerns. When the dean determines that "nothing was meant by the comments" and that there was "some question as to the actual words exchanged," the dean refuses to admonish the colleague who made the comments. Jack decides that he would like to pursue his options based upon his perception that the comments were discriminatory and "ageist."

In a second case, Wally Morehead has been a line coach at St. Stephen's for nearly forty years. One day at practice, an offensive linesman rolls into Wally's leg and Wally is seriously injured. Coach Molts visits Wally in the hospital and suggests, "Wally, you seem to be getting 'a little old in the tooth' to be mixing it up with these kids on the practice field." A year later, Wally is terminated at St. Stephen's when a new coach is hired and the entire assistant coaching staff is terminated. Wally now recalls the earlier comments made by Coach Molts.

These scenarios raise several questions relating to the Age Discrimination in Employment Act of 1967, more commonly known as the ADEA. Do the comments of essentially a co-worker (colleague) implicate the Act? Is the dean, as a "senior manager," legally responsible for the comments of a subordinate employee? Do the words "senior faculty" trigger at least a discussion of the import of the Act? What might Jack seek if he is, in fact, the victim of age discrimination? Are the comments made by Coach Moltz to Coach Morehead suggestive of discrimination? Is the University potentially liable for the comments of the dean or of Coach Moltz? Might any of these individuals (dean, coach, faculty member) be subject to personal liability? 


\section{Literature Review}

This study relies heavily on the Age Discrimination in Employment statute itself (1967), as well as the interpretative information provided by the Equal Employment Opportunity Commission, Feder (2010) and Glenn and Little (2004). Gaille (2017) and Terrell (2018) have provided much of the statistical information relating to the Act. Guerin (2011) discusses in detail questions relating to benefits and Lahey (2006) describes important procedural implications relating to the filing of claims by individuals who have claimed discrimination. In addition, various statutory materials have been referenced in an expansive thirteen case analysis. Issues relating to remedies are suggested by Martell (2016) and Marion (1986). The prior study of Hunter, Shannon, and Amoroso (2018) provides important background on the origins of debate on the question whether age discrimination demanded action by the Congress of the United States. Issues relating to the broader topic of ageism are referenced from research conducted by Doron et al. (2018), Sienna-Ayala (2017), Papke (2018), and Voss, Bodner, and Rothermund (2018).

\section{Background}

Sierra-Ayala et al. (2017) write that "Ageism is a very old concept and refers to negative stereotypes and prejudicial attitudes toward old age and how these are reflected in psychological and social problems." Ageism has been identified as the "third form of discrimination in our society after racism and sexism" (Stallard, Decker, \& Sellers, 2002). Butler (1969) coined the term "ageism" to refer to "a set of negative attitudes towards the elderly, social stereotypes, of prejudice and discrimination, maintained by the population."

The Age Discrimination in Employment Act, found at 29 U.S.C. $§ 621$ to 29 U.S.C. § 634 (generally, Feder, 2010), is a statute enacted by the Congress in 1967 pursuant to its commerce clause power that forbids employment discrimination against anyone at least 40 years of age in the United States (Woodruff, 1997; generally, Lahey, 2006). Glenn and Little (2004) noted that "Congress enacted the ADEA in response to findings of pervasive age bias in the American workplace. One of the most common age biases is that older people do not make good employees because productivity and competence decline with old age." In Hazen Paper Co. v. Biggins (1993), the United States Supreme Court noted that the essence of age discrimination can be seen in cases where an older person is fired simply because an employer believes old age affects their job capabilities (Griffin, Bayl-Smith, \& Barbour, 2004). Brooke and Taylor (2005) reported that "Studies have found that these kinds of stereotypes lead to older employees' exclusion from trainings, diminishing of skills, and ultimately premature exits from the workforce."

The Act contained a series of specific legislative findings:

(a) The Congress hereby finds and declares that:

(1) in the face of rising productivity and affluence, older workers find themselves disadvantaged in their efforts to retain employment, and especially to regain employment when displaced from jobs; 
(2) the setting of arbitrary age limits regardless of potential for job performance has become a common practice, and certain otherwise desirable practices may work to the disadvantage of older persons;

(3) the incidence of unemployment, especially long-term unemployment with resultant deterioration of skill, morale, and employer acceptability is, relative to the younger ages, high among older workers; their numbers are great and growing; and their employment problems grave;

(4) the existence in industries affecting commerce, of arbitrary discrimination in employment because of age, burdens commerce and the free flow of goods in commerce.

Pursuant to these findings, the Congress illuminated the purposes for the Act:

"It is therefore the purpose of this chapter to promote employment of older persons based on their ability rather than age; to prohibit arbitrary age discrimination in employment; to help employers and workers find ways of meeting problems arising from the impact of age on employment."

The bill was signed into law in 1967 by President Lyndon B. Johnson. The ADEA had a dual purpose. The Act prevents age discrimination and provides equal employment opportunity under conditions that were not explicitly covered in the passage of Title VII of the Civil Rights Act of 1964 (1964) which had outlawed discrimination based on five discreet areas: race, creed, color, national origin, and sex. The Act also applies to standards for pensions and other benefits provided by employers and required that information concerning the needs and special circumstances of older workers be provided to the general public.

The ADEA differs from the Civil Rights Act of 1964 in that the ADEA applies to employers of 20 or more employees (see 29 U.S.C. § 630(b)) rather than 15 or more employees under the Civil Rights Act. Both Acts do, however, apply to employers in industries "affecting interstate commerce." The 20 employees can include overseas employees. As the District Court noted in Haugh v. Schroder Investments (2003): "The purpose of Section 623(h)(2) was to protect the principle of sovereignty." Citing Morelli v. Cedel (1998, pp. 42-43), the Court further noted that "No nation has the right to impose its labor standards on another country. The ADEA also protects an employee, who is a United States citizen, working abroad for a United States corporation." However, ADEA protections for U.S. citizens working for U.S. employers operating abroad do not extend where such protections would violate the laws of that country (Torrico v. IBM, 2002).

\subsection{Amendments to the ADEA}

After the ADEA was enacted, the Act underwent a series of amendments to strengthen and expand its coverage of older employees. The ADEA was first amended in 1978 (Gitt, 1981), again in 1986, and then again in 1991 by the Older Workers Benefit Protection Act (Pub. L. 101-433) and the Civil Rights Act of 1991 (Pub. L. 102-166). 
In its original iteration, the ADEA covered employees between the ages of 40 and 65 . The upper age was extended to age 70, and then eliminated altogether. In 1978, enforcement authority was transferred from the Department of Labor to the Equal Employment Opportunity Commission (EEOC) (e.g., Peterman, 2018). As noted by Walta (2017, p. 1), "The ADEA charges the EEOC with administrative and enforcement responsibilities, including the authority to 'issue such rules and regulations as it may consider necessary or appropriate for carrying out' its duties"” (citing 29 U.S.C. § 628). The ADEA expressly prohibits discrimination and retaliation in the private sector. Later, in Gomez-Perez v. Potter (2008), the Supreme Court allowed federal workers who experience retaliation as a result of reporting age discrimination to sue for damages. Zelman and Douglas (2018) noted that "the first decision by United States Supreme Court this term [fall of 2018], Mount Lemmon Fire District v. Guido (2018), has broadened liability for small public employers nationwide by holding unanimously the Age Discrimination in Employment Act (ADEA) applies to all state and local public sector employers irrespective of size." Weston (2018) comments that "employing fewer than twenty people does not exempt a public entity employer from the ADEA's ban on age discrimination - a decision that expands the ADEA's protection [to] a whole new class of employees."

However, based on principles of federalism, in Kimel v. Florida Bd. of Regents, (2000), the United States Supreme Court held that state employees cannot sue states for monetary damages under the ADEA in federal court. The EEOC may still enforce the ADEA against states, and state employees may still sue state officials for declaratory and injunctive relief.

\section{Is Age Discrimination Still a Real Problem?}

Brandon Gaille (2017) has conducted extensive research on the signs of age discrimination and ageism in the workplace. There findings include the following:

- Biased comments that are specifically directed to an employee about their age, such as being told an employer wants a younger image, are the most common symptom of age discrimination.

- Older employees may be disciplined for actions that younger employees can do without consequence.

- Promotions that go to younger workers, despite the older worker being more qualified, are also a symptom of age discrimination (see also Voss, Bodner, \& Rothermund, 2018; Papke, 2018; Doron et al., 2018).

Perron and McCann (2018) point out that "About two-thirds [of Americans] agree that older Americans should be protected from age discrimination just like they are protected from discrimination on the basis of race, sex, national origin, or religion...." Gaille (2017) reports that "Discrimination in the workplace causes a hostile working environment for everyone." Writing for the AARP, Terrell (2018) reports that "According to the EEOC, over the past 25 years the percentage of workers 55 and older has doubled, jumping from 12 percent of the labor force in 1992 to 24 percent in 2017" (see also Gordon, 2017) 
Terrell (2018) cites the following evidence relating to the presence of age discrimination in the American economy:

- In 1997, there were just over 15,000 complaints filed with the EEOC relating to age discrimination. In 2008, a record 24,582 age discrimination complaints were filed, which Terrell (2018) notes "might be attributable in large part due to the Great Recession, when many workers alleged they were laid off because of their age" (see also Reavis \& Park, 2018).

- In 2017, more than 21,000 complaints for age discrimination were filed before the EEOC.

- Since the Age Discrimination Act was passed in 1967, more than \$91 million has been recovered from employers for victims of ageism.

- $64 \%$ of age discrimination charges contain a discharge of an employee.

- $14.8 \%$ of EEOC charges of age discrimination are found to be of merit.

- The percentage of workers who say that they have either seen or experience some form of age discrimination in the workplace stands at $64 \%$. Perron and McCann (2018) state that "About 3 in 5 older workers have either seen or experienced age discrimination in the workplace."

- $58 \%$ of American workers believe that age discrimination typically begins when workers reach their 50s.

- The percentage of older workers who say that they plan to work for several more years so they can retire in a comfortable manner is $29 \%$.

- $16 \%$ of retirees say that they may have to return to work because they can't make ends meet with their retirement.

\section{Scope of Protection}

The ADEA includes a broad ban against age discrimination against workers over the age of forty (generally, Kaminshine, 1990), and also specifically prohibits:

- Discrimination in hiring, promotions, wages, and termination of employment and layoffs.

- Statements of specifications in age preference or limitations.

- Denial of benefits to older employees: an employer may reduce benefits based on age only if the cost of providing the reduced benefits to older workers is the same as the cost of providing full benefits to younger workers (see Guerin, 2011). These benefits may include life insurance, health insurance, disability benefits, pensions, and other retirement benefits. 
- Since 1986, the Act has prohibited mandatory retirement in most sectors of the economy, with phased elimination of mandatory retirement for tenured workers, such as college professors, in 1993 (Del Po, 2000; Earle \& Del Po-Kulow, 2015).

\section{Types of Age Discrimination}

As described by Rocketswag.com (2018) (adapted from Hunter, Shannon, \& Amoroso, 2018, p. 72), age discrimination may take many forms. These include:

- "Direct discrimination: This is said to take place when an individual is not favored, solely because of his/her age."

- "Indirect discrimination: A company or an employer is said to be engaging in indirect discrimination against an employee or spirant (applicant) to a job, if they have a strategy of categorizing individuals of a particular age group by putting them at a disadvantage in comparison to other group of employees or aspirants."

- Harassment: The EEOC (2018) reports that "Harassment can include, for example, offensive or derogatory remarks about a person's age." Rocketswag (2018) continues: "Telling ageist jokes, bullying or name calling solely on the basis of age amounts to harassment." The EEOC (2018) continues "Although the law doesn't prohibit simple teasing, offhand comments, or isolated incidents that aren't very serious, harassment is illegal when it is so frequent or severe that it creates a hostile or offensive work environment or when it results in an adverse employment decision (such as the victim being fired or demoted)." This view comports with the decision reached by the United States Supreme Court in Shager v. Upjohn Corporation (1989), where the Court announced what has been termed the "stray remarks doctrine." Justice Sandra Day O'Connor wrote that "stray remarks" made by "non-decision making coworkers or remarks made by decision-making supervisors outside of the decisional process" are insufficient evidence of an employer's discriminatory attitude. "Without additional evidence of discrimination," stated Justice O'Connor, a gender discrimination claim can be and should be dismissed by the court before trial. This view relating to gender discrimination seems to parallel that of the EEOC relating to age discrimination as well.

- "Victimization: In this context, an individual is said to be victimized, if he/she is being treated less favorably because he/she has filed a complaint of age discrimination or he/she has agreed to testify for some other victim of age discrimination" (Rocketswag.com, 2018). This is sometimes referred to as retaliation (Peeler \& Haffner, 2015).

\section{Are There any Exceptions to the ADEA?}

Mandatory retirement based on age is permitted for executives over age 65 in high 
policy-making positions who are entitled to a pension over a minimum yearly amount (Shaiken, 1981). In addition, an age limit may be legally specified in circumstance where age has been shown to be a "bona fide occupational qualification [BFOQ] reasonably necessary to the normal operation of the particular business" (see 29 U.S.C. § 623(f)(1); Schiff, 1993) and either "all or substantially all individuals excluded by the limit involved are in fact unqualified, or some of the individuals so excluded possess a disqualifying trait that cannot be ascertained except by reference to age" (see 29 C.F.R. $§ 1625.7(b)$ ).

In practice, BFOQs for age are limited to the "obvious" (for example, hiring a young actor to play a young character in a movie (Frank, 2001)) or when public safety is at stake (for example, in the case of age limits for pilots and bus drivers). As noted by McCann (2018), "Some occupations, such as pilots, certain positions in the military or law enforcement (Schiff, 1993), and state judges in most jurisdictions, still encounter mandatory retirement" (citing Hannon, 2015).

The United States Code (29 U.S.C. § 623(j)) provides that, with respect to firefighters and law enforcement officers, states may "fail or refuse to hire or to discharge any individual because of such individual's age ... [T] he employer has complied with section 3(d)(2) of the Age Discrimination in Employment Amendments of 1996 if the individual was discharged after the date described in such section, and the individual has attained . . . the higher of . . . the age of retirement in effect on the date of such discharge under such law; and . . age 55." The Defense Civilian Personnel Management Service (2006) noted that ""The legislative intent behind the special retirement provisions... was to provide for their early retirement based on a determination that these positions should be composed . . . of young men and women physically capable of meeting the vigorous demands of occupations that are more physically taxing than most in the Federal service." Walta $(2017$, p. 8) states that "Where the BFOQ is asserted to be a measure protecting public safety, the defendant "must prove that the challenged practice does indeed effectuate that goal and that there is no acceptable alternative which would better advance it or equally advance it with less discriminatory impact"' (see 29 C.F.R. $\S 1625.6(b))$.

As noted earlier, the ADEA did at one point contain an exception for tenured faculty at institutions of higher education. That exception has since expired (Ruebhausen, 1988). However, the ADEA does allow an institution of higher education to offer tenured employees who become eligible to retire "supplemental benefits" to encourage them to voluntarily retire (see Hill, 2017). Supplemental benefits are classified as benefits above and beyond retirement or severance benefits generally offered to employees of the institution.

\subsection{Statutory Defenses to ADEA Claims}

There are a number of statutory defenses to ADEA claims. These include:

- Employers may enforce waivers of age discrimination claims made without EEOC or court approval if the waiver is "knowing or voluntary."

- Valid arbitration agreements between employers and employees covering a dispute are subject to compulsory arbitration and no court action can be 
brought until the arbitration process has been utilized (Rios, 1999; Ahern, 2017).

- Employers can discharge or discipline an employee for "good cause" (e.g., Befort, 2017) regardless of the employee's age.

- Employers can take an action based on "reasonable factors other than age (RFOA)." Walta (2017, p. 7) notes that a RFOA is a "non-age factor that is objectively reasonable when viewed from the position of a prudent employer mindful of its responsibilities under the ADEA under like circumstances" (citing 29 C.F.R. $§ 1625.7(\mathrm{e})(1)$ ). Whether a determination will qualify as a RFOA is determined on a "case-by-case basis," and the relevant considerations include:

(i) the extent to which it is related to a stated business purpose;

(ii) the extent to which it was accurately defined and fairly applied;

(iii) the extent to which it limited the discretion to assess or select employees for adverse action based on subjective criteria or negative age-based stereotypes;

(iv) the extent to which the adverse impact on older workers was assessed; and

(v) the degree of the harm to individuals within the protected age group, in terms of both the extent of injury and the numbers of persons adversely affected, and the extent to which reasonable steps were taken to reduce the harm (29 C.F.R. § 1625.7(e)(2)).

- Bona fide occupational qualifications, valid seniority systems, or the operation of non-discriminatory employee benefit or early retirement plans.

- Voluntary early retirement incentives.

\section{Waiver Provisions}

A controversial area under the ADEA involves waivers. An employee may waive his rights under the ADEA if such waiver was both "knowing and voluntary" (Padilla, 2018). The statute sets forth detailed requirements for establishing these two elements.

According to Section 626(f)(1) of the Act, a waiver is knowing and voluntary if:

(A) the waiver is part of an agreement between the individual and the employer that is written in a manner calculated to be understood by such individual, or by the average individual eligible to participate;

(B) the waiver specifically refers to rights or claims arising under this chapter;

(C) the individual does not waive rights of claims that may arise after the date the waiver is executed; 
(D) the individual waives rights or claims only in exchange for consideration in addition to anything of value to which the individual already is entitled;

(E) the individual is advised in writing to consult with an attorney prior to executing the agreement; $(\mathrm{F})(\mathrm{i})$ the individual is given a period of at least 21 days within which to consider the agreement; or

(ii) if a waiver is requested in connection with an exit incentive or other employment termination program offered to a group or class of employees, the individual is given a period of at least 45 days within which to consider the agreement;

(G) the agreement provides that for a period of at least 7 days following the execution of such agreement, the individual may revoke the agreement, and the agreement shall not become effective or enforceable until the revocation period has ended.

The party asserting the validity of the waiver has the burden of proving that the waiver was knowing and voluntary. The United States Supreme Court, in Meacham v. Knolls Atomic Power Lab (2008), held that the employer, not the employee, bears the burden of proving that a layoff or other action that disadvantages or harms older workers more than other employees was based not on age but on some other "reasonable factor."

Interestingly, a waiver cannot be used to interfere with an employee's right to file an age discrimination charge or participate in an EEOC investigation or proceeding.

In Oubre v. Entergy Operations, Inc. (1998), an employee received severance pay in return for waiving any claims against the employer, but the waiver did not fully comply with the ADEA's waiver requirements. The United States Supreme Court, reasoning that receipt and retention of severance benefits does not ratify a statutorily invalid waiver, held that the plaintiff did not have to return the money before bringing suit.

\section{Procedures for Filing an ADEA Claim}

Walta $(2017$, p. 2) notes that "In order to bring a claim under the ADEA, an employee must file a timely charge with the EEOC's filing a claim under the ADEA differ between states who have adopted their own age discrimination laws. If a state has adopted its own age discrimination statute (Hunter, Shannon, \& Amoroso, 2018, p. 71; Neumark, Burn, Button, \& Chehras, 2017), the ADEA requires the claimant to file with the state Fair Employment Practices (FEP) office within 300 days. In states without a statute, the claimant must file with the EEOC within 180 days. At that point, the EEOC can either dismiss the claim, at which point the claimant may pursue a civil action against an employer in court, or the EEOC can seek to settle the case or mediate. If the settlement or mediation is unsuccessful, the EEOC can then sue, or if the EEOC chooses not to sue, the individual claimant may decide to initiate a suit. Because of the backlog of cases before the EEOC (Lahey, 2006), statistics indicate that "over 95 percent of employment discrimination cases are brought by private attorneys, not the EEOC" as a private action. 


\section{Retaliation}

The ADEA expressly prohibits retaliation against an employee who has filed an ADEA claim in the private sector - although there is some evidence that there may be a "backlash" against the "initial wave of plaintiff success" (Long, 2018). The United States Supreme Court addressed the issue of retaliation in Gomez- Perez v. Potter (2008), holding that the ADEA does indeed prohibit retaliation in the public sector (federal government employment) as well. The Supreme Court relied on precedents established in cases involving other antidiscrimination statutes and ruled that a prohibition against retaliation is encompassed within the general prohibition against age discrimination and that it extended into the public sector.

In order to state a claim for retaliation under the a plaintiff must allege that "(1) he engaged in statutorily protected activity; (2) that he suffered a materially adverse action by his employer; and (3) a causal link connects the two" (Jones v. Bernanke, 2009) and in Tomasello v. Rubin (1999), the court noted that "[T] he test for determining retaliation under the ADEA and Title VII is identical."

Because the ADEA statute covers individuals who are age forty or older, younger employees are not protected from age discrimination under the Act. As a result, employers may engage in what has been termed as "reverse discrimination"-by enacting employment practices that favor employees over the age of forty - without violating the statute. As stated by the Court, although the ADEA "forbids discriminatory preference for the young over the old," it does not prohibit favoring the old over the young, even when the younger and older employees are within the protected class, i.e., age forty or older (see General Dynamics Land Systems, Inc. v. Cline, 2004). In contrast, the Court has separately held that the ADEA does prohibit discrimination against older employees in favor of younger employees who are older than forty years old.

\section{Remedies}

The EEOC (2018) provides guidance on the scope and nature of potential liability under the ADEA: "The harasser can be the victim's supervisor, a supervisor in another area, a co-worker, or someone who is not an employee of the employer, such as a client or customer" (see Coletta. 2018, p. 451). Because the ADEA "prevents employers from predicating employment decisions on arbitrary age limits regardless of an employee's ability to perform a given job," in order to achieve this goal, the ADEA "authorizes courts to grant relief to eradicate such discrimination and to return the victims to the positions they would have occupied had the discrimination not occurred. To that end, a court may grant 'such legal and equitable relief as may be appropriate to effectuate the purposes of [the Act]' " (Marion, 1986, p. 302, quoting 29 U.S.C. $§ 626(b)$ (1982)).

The remedies available under the ADEA are patterned on the Fair Labor Standards Act (1938), and may include the award of an injunction, a requirement that an employee be hired by an employer (compelled employment), reinstatement of an employee, front pay (money awarded for lost compensation during the period between judgment and reinstatement, or if reinstatement is not feasible, instead of reinstatement (Mantell, 2016)), promotion, and an 
award of back pay (generally, Marion, 1986). In addition, a willful or intentional violation of the act gives rise to what are termed as liquidated damages, which are generally computed by doubling the amount awarded to the plaintiff.

In Trans World Air Lines v. Thurston (1985), the United States Supreme Court held that "a violation of the Act [is] 'willful' if the employer knew or showed reckless disregard for the matter of whether its conduct was prohibited by the ADEA." Upon proof of a claim of age discrimination, a plaintiff is also entitled to reasonable attorney's fees and costs. In addition, anyone who interferes with the EEOC's performance of its duties under the ADEA is subject to criminal penalties amounting to a fine or up to one year of prison, or both.

Courts have struggled with defining the extent of liability in ADEA actions. It is generally accepted that liability for a violation of the ADEA rests with the employer. For example, in Shager v. Upjohn Co. (1990), the Seventh Circuit Court of Appeals reversed a lower court's grant of a summary judgment motion in favor of the employer, finding that an intentional act of an employee performed within the scope of his authority is "an act of the employer" and is properly imputed to the employer under the application of the doctrine of respondeat superior. In addition, the Seventh Circuit implied that in addition to the employer, an individual supervisor could also be held personally liable under the ADEA (see Greer, 1994). The Court stated that "[t]he statutory language ... could mean ... that [the supervisor] is liable along with [the employer], or even possibly instead of [the employer]." This decision, however, if met with general acceptance, could open up a new area of potential liability (and research) in the area of age discrimination.

\section{Commentary: Questions Answered or Unresolved?}

According to Bastedo, Altbach, and Gumport (2016), "There are more than 1.5 million full-and part-time faculty members in America's 4,700 institutions of post secondary education." Hill (2017) adds: "Professors at all rank levels, though, seem to be working harder and logging in more hours each week as their teaching loads and service responsibilities have not declined." Yet, comments referenced in the opening scenario are unfortunately common place. Whether or not the comments made by a participant in a meeting, called by the dean, would amount to age discrimination would involve a careful examination of the viewpoint expressed by Justice O'Connor in crafting the "stray remarks doctrine." Since the comments were made by "non-decision making coworker," and not by a decision-making supervisor, they would probably not rise to the level of age discrimination and would be insufficient evidence of an employer's discriminatory attitude. As Justice O'Connor stated, "Without additional evidence of discrimination," a gender discrimination claim can be and should be dismissed by the court before trial. However, now being informed of the potential discriminatory impact of the comments, and that they were not taken as a "joke," the dean would be well within her authority to issue at least a "gentle reminder" to the speaker and others that such comments are out of bounds and will not be tolerated in any future meetings or faculty conversations. Failing to do so might provide that type of "additional evidence" necessary to prosecute a claim for age discrimination.

With reference to Coach Molts, it could be argued that the Coach is Morehead's direct 
supervisor and "decision maker" as to his future status as a coach. However, the fact that Coach Morehead waited until a year after the alleged words had been uttered will almost certainly doom his claim of age discrimination under the ADEA but not necessarily under a state statute that deals with discrimination based on age.

In either event, since the offending individual is an employee of St. Stephen's, the University might have to respond in damages for the offending comments under the theory of respondeat superior. Whether any of the individuals (coach, dean, faculty member) would bear personal liability in addition to the University is still an open-yet very interesting - question that merits further research and discussion.

\section{References}

Ahern, S. (2017). Waiving goodbye to your rights: Retaliation and invalidity in the context of waivers under Title VII, the ADA, and the ADEA. Boston University Law Review, 97, 659-680.

Bastedo, M. N., Altbach, P. G., \& Gumport, P. J. (Eds). (2016). American higher education in the twenty-first century. Social, political, and economic challenges $\left(4^{\text {th }} \mathrm{ed}\right.$.). Baltimore, Md.: Johns Hopkins University Press.

Befort, S. F. (2017). Employee handbooks and policy statements: From gratuities to contracts and back. Employee Rights and Employment Policy Journal, 30, 307-324.

Brooke, L., \& Taylor, P. (2005). Older workers and employment: Managing age relations. Ageing \& Society, 25(3), 415-429.

Butler, R. N. (1969). Another form of bigotry. Gerontologist, 9, 243-246.

Coletta, K. N. (2018). Sexual harassment on social media: Why traditional company sexual harassment policies are not enough and how to fix it. Seton Hall Law Review, 48, 449-473.

Defense Civilian Personnel Management Service. (2006). Special retirement provisions for law enforcement officers, firefighters and air traffic controllers: A guide for human resource specialists. Available: https:www.dodfire.com/Retiremant/cpms_retire_guidance.pdf (May 2006).

Del Po. M. C. (2000). Too old to die young, too young to die now: Are early retirement incentives in higher education necessary, legal, and ethical? Seton Hall Law Review, 30, 827-845.

Doron, I. et al. (2018). Ageism and anti-ageism in the legal system: A review of key themes. In Ayalon, L. \& C. Tesch-Romer (Eds.). Contemporary perspectives on ageism (303-319). New York, N.Y.: Springer International.

Earle, B., \& Del Po-Kulow. (2015). The "deeply toxic" damage caused by the abolition of mandatory retirement and its collision with tenure in higher education: A proposal for statutory repair. Southern California Interdisciplinary Law Journal, 24, 369-418.

EEOC (Equal Employment Opportunity Commission. (2018). Sexual harassment. Available: 
https://www1.eeoc.gov/laws/types/sexual_harassment.cfm?renderforprint=1(Accessed December 23, 2018).

Feder, J. (2010). The age discrimination in employment act (ADEA): A legal overview. Congressional Research Service.

Available:

http://congressionalresearch.com/97-479/document.php (June 23, 2010).

Frank, M. J. (2001). Justifiable discrimination in the news and entertainment industries: Does Title VII need a race or color BFOQ? University of San Francisco Law Review, 35, 473-525.

Gaille, B. (2017). 27 surprising age discrimination in the workplace statistics. Available: https://brandongaille.com/25-surprising-age-discrimination-in-the-workplace (May 23, 2017).

Gitt, C. E. (1981). The 1978 amendments to the age discrimination in employment act- A legal overview. Marquette Law Review, 64, 607-656.

Glenn, J. J., \& Little, K. E. (2004). A study of the age discrimination in employment act of 1967. GP Solo. Available: https://www.americanbar.org/publications/gp_solo/2014/november_december/a_study_the_a ge_discrimination_employment_act_1967.html (Accessed January 10, 2019).

Gordon, P. A. (2017). Age diversity in the workplace. In de Aquino, C.T.E. \& R.W. Robertson (Eds.). Diversity and inclusion in the global workplace (pp. 31-47). New York, M.Y.: Palgrave Macmillan.

Greer, C. (1994). "Who, me?" A supervisor's individual liability for discrimination in the workplace. Fordham Law Review, 62(6), 1835-1850.

Griffin, B., Bayl-Smith, P., \& Barbour, J. P. (2017). Age discrimination and older workers. In Nelson, T. D. (Ed.), Ageism, stereotyping and prejudice against older persons (Chapter 8). Boston, Mass.: MIT Press.

Guerin, L. (2011). Employment law: The essential HR desk reference (1 $1^{\text {st }}$ ed.). Berkeley, Cal.: NOLO.

Hannon, K. (2015). Is it time to abolish mandatory retirement? Forbes. Available: https://www.forbes.com/.../is-it-time-to-abolish-mandatory-retirement (August 2, 2015).

Hill, R. (2017). Faculty buyout packages: an emerging higher ed trend? The Evolllution. Available:

https://evolllution.com/managing-institution/operations_efficiency/faculty-buyout-packages-a n-emerging-higher-ed-trend-part-1 (February 8, 2017).

Hunter, R. J., Shannon, J. H., \& Amoroso, H. J. (2018). A fresh look at an old problem- Age discrimination in employment: Is there a demographic and political trap? Journal of Public Administration and Governance, 8(1), 68-85.

Kaminshine, S. J. (1990). The cost of older workers, disparate impact and age discrimination in employment. Florida Law Review, 42, 229-322. 
Lahey, J. N. (2006). How do age discrimination laws affect older workers? Center for Retirement Research (Boston College). Available: http://crr.bc.edu/briefs/how-do-age-discrimination-laws-affect-older-workers/ (October 2006).

Long, A. B. (2018). Retaliation backlash. Washington Law Review, 93, 715-766.

Mantell, R. S. (2016). Front pay in employment cases: Calculating future losses. Available: https://theemploymentlawyers.com/.../2016/11/front-pay-damages.pdf (November 2016).

Marion, J. H. (1986). Legal and equitable remedies under the age discrimination in employment act. Maryland Law Review, 45, 298-351.

McCann, L. (2018). The Age Discrimination in Employment Act at 50: When will it become a "real" civil rights statute? American Bar Association Journal of Labor and Employment Law, 89-104.

Neumark, D., Burn, I., Button, P., \& Chehras, N. (2017). Do state laws protecting older workers from discrimination reduce age discrimination in hiring? Evidence from a field experiment. NBER Working Paper No. 25369. Available: http://www.mrrc.isr.umich.edu/publications/papers/pdf/wp349.pdf (March 2017)

Padilla, S. (2018). For clarity's sake: redefining the knowing and voluntary standard in severance agreements. Fordham Urban Law Journal, 45, 839-874.

Papke, D. R. (2018). Ageism: A powerful nemesis for effective workplace discrimination law. Marquette Law School Legal Studies Paper No. 18-25. Available at SSRN: https://ssrn.com/abstract=3277566; http://dx.doi.org/10.2139/ssrn.3277566 (November 2018).

Peeler, R., \& Haffner, E. (2015). Selected developments in retaliation law. American Bar Association [Online]. Available: https://www.Americanbar.org/contact/dam/aba/events/labor-law/2015/november (November 2015).

Perron, R., \& McCann, L. (2018). 50 years after ADEA: Perspectives of age discrimination in the workplace. Innovation in Aging, 2(Supp. 1), 319. Available: https://www.ncbi/nim.nih.gov/pmc/articles/PMC6227331/ (November 2018).

Peterman, D. E. (2018). Socioeconomic status discrimination. Virginia Law Review. 104, 1285-1357.

Reavis, H. D., \& Park, A. R. (2018). Boomers after the bust. In Rizzo, M., S. Anderson, \& B. Fritzsch (Eds.). Ageism and employment discrimination trends after the great recession (pp. 742-749). Hoboken, N.J.: John Wiley \& Sons.

Rios, F. D. (1999). Mandatory arbitration agreements: Do they protect employers from adjudicating Title VII claims? St. Mary's Law Journal, 31, 199-254. 
Rocketswag.com. (2018). Types of age discrimination. Available: http://www.rocketswag.com/retirement/elderly-law/age-discrimination/Types-Of-Age-Discri mination.htm (Accessed December 22, 2018).

Ruebhausen, O. M. (1988). The age discrimination in employment act amendments of 1986: Implications for tenure and retirement. The Journal of College and University Law, 14, 561-574.

Schiff, M. (1993). The Age Discrimination in Employment Act: Whither the bona fide occupational qualification and law enforcement exemptions? St. John's Law Review, 67(1), 13-54.

Shaiken, M. A. (1981-1982). Will you still need me... when I'm sixty-four: Forced retirement for executives under the ADEA. University of Baltimore Law Review, 11, 256-271.

Sierra-Ayala, I. et al. (2017). Ageism: Discrimination that must disappear. Journal of Geriatrics and Palliative Care, 6(1), 1-3.

Stallard, J. M., Decker, I. M., \& Sellers, J. B. (2002). Health care for the elderly: A social obligation. Nursing Forum, 37, 5-15.

Terrell, K. (2018). Age bias complaints rise among women and minorities. AARP. Available: https://www.aarp.org/work/working-at-50-plus/info-2018/age-discrimination-increases-wome n-minorities.html (June 28, 2018).

Voss, P., Bodner, E., \& Rothermund, K. (2018). Ageism: The relationship between age stereotypes and age discrimination. In Ayalon, L. \& C. Tesch-Romer (Eds.). Contemporary perspectives on ageism (pp. 11-31). New York, N.Y.: Springer International.

Walta, J. (2017). Panel: Age discrimination issues in higher education. Journal of Collective Bargaining in the Academy, National Center for the Study of Collective Bargaining in Higher Education, Proceedings of the $44^{\text {th }}$ National Conference, Article 46: 1-16. Available: http://www.thekeep.eiu.edu/cgi/viewcontent.cgi?article=1698\&context=jcba (March 28, 2017).

Weston, K. (2018). Annual survey of federal en banc and other significant cases: Public entities become a model against age discrimination: Expanding the definition of "employer" in Guido v. Mount Lemmon Fore District. Boston College Law Review Electronic Supplement, 59, 279-296.

Woodruff, B. B. (1997). Unprotected until forty: The limited scope of the Age Discrimination in Employment Act of 1967. Indiana Law Journal, 73(4), 1295-1312.

Zelman, J. G., \& Douglas, J. G. (2018). United States: Supreme Court rules ADEA applies to all public employees regardless of size and leaves the door open to personal liability. Mondaq. Available:http://www.mondaq.com/unitedstates/x/755820/employment+litigation+tribunals/S upreme+Court+Rules+ADEA+Applies+To+All+Public+Employers+Regardless + Of + Size $+\mathrm{A}$ nd+Leaves+The+Door+Open+To+Personal+Liability ((November 19, 2018). 


\section{Cases Cited}

Gomez-Perez v. Potter. (2008). 553 U.S. 474 (United States Supreme Court).

Haugh v. Schroder Investments. (1985). 469 U.S. 111 (United States Supreme Court).

Hazen Paper Co. v. Biggins. (1993). 507 U.S. 604 (United States Supreme Court).

Jones v. Bernanke. (2009). 557 F.3d 670 (United States Circuit Court of Appeals, D.C.

Circuit).

Kimel v. Florida Bd. of Regents. (2000). 528 U.S. 62 (United States Supreme Court).

Meacham v. Knolls Atomic Power Lab. (2008). 554 U.S. 84 (United States Supreme Court).

Morelli v. Cedel. (1998). 141 F.3d 39 (Court of Appeals, $2^{\text {nd }}$ Circuit).

Mount Lemmon Fire District v. Guido. (2018). 139 S. Ct. 22 (United States Supreme Court).

Oubre v. Entergy Operations, Inc. (1998). 522 U.S. 422 (United States Supreme Court).

Shager v. Upjohn Corporation. (1990). 913 F.2d 398 (United States Court of Appeals, $7^{\text {th }}$

Circuit).

Tomasello v. Rubin. (1999). 167 F.3d 612 (United States Circuit Court of Appeals, D.C. Circuit).

Torrico v. IBM. (2004). 319 F. Supp. 2d 390 (United States District Court for the Southern District of New York).

Trans World Air Lines v. Thurston. (1985). 469 U.S. 111 (United States Supreme Court).

\section{Statutes}

Age Discrimination in Employment Act. (1967). 29 U.S.C. § 621 to 29 U.S.C. § 634.

Civil Rights Act of 1964. (1964). Pub.L. 88-352, 78 Stat. 241.

Civil Rights Act of 1991. (1991). Pub. L. 102-166.

Fair Labor Standards Act of 1938. (1938). 29 U.S.C. § 203.

Older Workers Benefit Protection Act. (1990). Pub. L. 101-433.

\section{Copyright Disclaimer}

Copyright for this article is retained by the author(s), with first publication rights granted to the journal.

This is an open-access article distributed under the terms and conditions of the Creative Commons Attribution license (http://creativecommons.org/licenses/by/4.0/). 